\title{
Studerendes digitale læringsstrategier
}

\author{
Læring og Medier (LOM) nr. 23, 2020
}

\author{
Mikkel Hvidtfeldt Andersen, IT-Universitetet \\ Inger-Marie F. Christensen, Syddansk Universitet \\ Ulla Konnerup, Aalborg Universitet
}

\section{Indledning}

Dette temanummer af LOM sætter fokus på studerendes digitale læringsstrategier. Temanummeret består af forskningsbaserede artikler, der bidrager med viden om hvilke digitale læringsstrategier, de studerende på ungdoms- og videregående uddannelser benytter sig af, hvilke faktorer, der påvirker disse strategier, samt hvem der har en rolle ift. etableringen af dem. De studerendes anvendelse af digital teknologi i og udenfor undervisningslokalet er et emne, der optager mange. Både undervisere og studerende angiver, at den digitale teknologi kan være et forstyrrende element (I.-M. F. Christensen, 2017; P. H. Christensen, 2018). Samtidig vil mange studerende nødigt undvære deres digitale devices, fordi det går for langsomt at skrive noter i hånden, giver manglende struktur og søgemuligheder, betyder en dekobling fra deres virtuelle sociale netværk og samarbejde m.m.

Henderson, Selwyn, Finger og Aston (2015) konkluderer netop på basis af en undersøgelse af australske universitetsstuderendes anvendelse af digital teknologi, at de studerende beskriver teknologi som brugbar og hjælpsom, når denne understøtter logistikken omkring deres studieliv: "helping students 'stay in the loop', making research 'easier' and generally managing and organising their studies" (2015, s. 317). Samme undersøgelse finder, at brug af digital teknologi i relation til undervisning og læring følger den dominerende universitetsmodel for transmission af viden, hvor den digitale teknologi nok betyder nye måder at tilgå viden på, f.eks. via video, der kan give læringen et visuelt element, men som ikke medfører innovation i forhold til undervisningsmetoder. Der er i overvejende grad stadig tale om passiv læring fremfor "more fluid, networked, connected or individually driven forms of learning" (Henderson et al., 2015, s. 317), og digital teknologi benyttes kun i begrænset omfang på mere kreative måder i relation til undervisning og læring.

I en tid, hvor alting digitaliseres, herunder undervisning, uddannelser og læring, er det vigtigt at stille skarpt på de studerendes digitale læringsstrategier. Disse strategier bliver en stadig mere afgørende faktor, fordi de er med til at åbne op eller lukke for bl.a. de studerendes muligheder for deltagelse, læring samt interaktion med medstuderende og undervisere. Dermed påvirker strategierne både studerendes sociale såvel som faglige integration. De studerende kan ikke nødvendigvis overføre deres private og sociale brug af digital teknologi til en undervisnings- og læringskontekst:

\footnotetext{
"Students today would appear to be more digitally literate than previous generations because many have grown up immersed in technology-rich environments, but research has shown that this does not necessarily equate to confidence, especially in an educational context."
}

(Johnson et al., 2016, s. 24) 
De studerende har behov for et nyt digitalt repertoire, herunder akademisk digital dannelse (Caviglia, Dalsgaard, O'Donovan \& Andersen, 2019), således at de kompetent kan agere og handle i det digitale landskab og ikke fastholdes i en rolle som passive forbrugere af digitale læremidler og informationer.

Dette temanummer viser billeder af studerendes digitale læringsstrategier i 2020 i en dansk kontekst, og artiklerne giver forskellige perspektiver på de studerendes digitale tilgange og digitale aktiviteter i relation til læring og studieliv. På tværs af artiklerne er der varierende tolkninger af begrebet læringsstrategi. Den overordnede fælles forståelse er, at begrebet dækker, hvorledes den lærende selv angriber det at lære. Hvordan udnytter de studerende de tilgængelige rammer og ressourcer, hvordan planlægger og organiserer de, og hvordan samarbejder de? Er den strategi, den enkelte vælger, et bevidst eller ubevidst valg?

I nogle artikler anskues læringsstrategi overvejende kognitivistisk og forstås som informationsbearbejdelse og erkendelse på det niveau, hvorpå den enkelte befinder sig. Hvorimod andre artikler repræsenterer et (social)konstruktivistisk perspektiv, hvor studerendes strategier og tilgange til læring anerkendes som medskabende og som bidrag til at forme undervisningen. Læringsstrategier kan udvikle sig løbende afhængigt af kontekst og artefakter. Derfor er det spændende at undersøge, hvorledes digitale teknologier påvirker de studerendes læringsstrategier. Artiklerne konkluderer, at der ikke er opstået en ny særskilt digital læringsstrategi, men en strategi, hvor de digitale muligheder understøtter og bidrager til udvikling af nye strategier.

Artiklerne undersøger digitale læringsstrategier med en række metodiske greb så som observationer af, samtaler om og sproganalyser af studerendes praksisser. Man kan sige, at bredden af tilgange afspejler aktuelle tendenser på feltet, der de senere år har konvergeret mod et holistisk perspektiv ved en insisteren på at undersøge den hele studerende ud fra forskellige kognitive, affektive, fysiske, kulturelle og sociale vinkler (Mccombs, 2017). Dermed er banen kridtet op til at forholde sig til spændingen mellem forskellige teoretiske positioners metodiske implikationer. I denne henseende interesserer hovedparten af artiklerne sig især for forholdet mellem fælles og individuelle digitale læringsstrategier og dette informerer et relationelt blik i de empiriske designs. Der er således eksempelvis indsamlet materiale om læringsrum og -miljø, studiepraksisser og faglige dialoger.

Temanummerets artikler viser, hvordan nogle studerende allerede er i besiddelse af et brugbart digitalt repertoire, hvorimod andre studerende mangler redskaber og kompetencer. Der er således behov for fremadrettet at undersøge, hvordan undervisere og uddannelser kan stilladsere og rammesætte studerendes anvendelse af digital teknologi. De studerende skal understøttes $i$ at udvikle eget repertoire, egne digitale læringsstrategier, sådan at den digitale teknologi ikke bliver en barriere, dvs. et negativt forstyrrende element, men en produktiv forstyrrelse, der understøtter læring, interaktion og samarbejde. En udfordring for underviseren er at balancere struktur og frihed, sådan at de studerende dels har frihed til at udforske og udnytte egne læringsstrategier og dels tilbydes struktur og stilladsering via rammesætning og læringsdesign, dvs. "structured freedom" (Ryberg, Bertel, Sørensen, Davidsen \& Konnerup, 2020).

\footnotetext{
"Structured freedom expresses the tension between on the one hand, a wish for students to take ownership of the learning process and practice investment of self in the learning process, and on the other hand, the need to design a structure within which this can occur."
}

(Ryberg et al., 2020, s. 7)

Den digitale teknologi tilbyder et mulighedsrum i forhold til læring, og det kræver bevidst strategiudvikling at kunne gribe og udnytte disse muligheder. Her kan underviserens didaktisering medvirke til at synliggøre mulighedsrummet og give plads til de studerendes bevidste udforskning af digital teknologi i en læringskontekst 
Herunder præsenterer vi kort temanummerets artikler. I skrivende stund er endnu en artikel i proces. God læselyst.

\section{Præsentation af temanummerets artikler}

I artiklen "Sammen, hver for sig: universitetsstuderendes læringsstrategier under COVID19nedlukningen" undersøger Andersen, Gerwien og Kammer, hvordan universitetsstuderende håndterede omlægningen til digital undervisning og læring, som fulgte af nedlukningen i foråret 2020. Artiklens formål er at afdække, hvordan de studerende navigerede i den radikalt forandrede situation for læring og studieliv, hvor det fysiske sted for deres uddannelse og læring var fraværende, og hvilke strategier de anvendte. Forfatterne udvikler en teoretisk ramme bestående af begreberne praksisfællesskaber, personlige læringsmiljøer, baner og rum samt medieret interaktion. Denne teoretiske ramme anvendes i analysen af undersøgelsens empiriske materiale, der består af kvalitative interviews foretaget under nedlukningen med 23 studerende fra IT-Universitetet i København. I analysen afdækkes de studerendes læringsstrategier i forhold til den tilrettelagte undervisning og det tilrettelagte gruppearbejde, det selvorganiserede studiearbejde og studielivet mere generelt. Fastholdelse af motivation og koncentration fremhæves som en særlig udfordring under nedlukningen. På baggrund af analysen, peger forfatterne på fremkomsten af 3 former for virtuelle læringsfællesskaber, nemlig undervisningsfællesskaber, studiefællesskaber samt støttefællesskaber og konkluderer, at de studerendes faglige eller sociale relationer før nedlukningen spillede en rolle for (gen)dannelse af praksisfællesskaber under nedlukningen.

Morten Winther Bülows ærinde i artiklen "Læringsstrategier på ungdomsuddannelserne" er at identificere mønstre i gymnasieelevers gengivelser af egne læringsstrategier. Bülow har undersøgt elevers oplevelser af forløb, der vekslede mellem blended learning, virtuel undervisning og hybride formater og anlægger et elev-centreret og økologisk perspektiv på læringsstrategier for også at favne de teknologiske, de rummelige og de sociale kontekster, der har indvirkning på elevernes strategier. Artiklen søger at besvare de to forskningsspørgsmål: 1) Hvilke dimensioner anvender eleverne i deres selvfremstilling af egne læringsstrategier? 2) Hvilke læringsstrategiske mønstre kan identificeres? Bülow har foretaget en abduktiv undersøgelse, hvor der veksles mellem teoretiske refleksioner og empirisk arbejde, hvori indgår elevers grafiske illustrationer af egen ressourceøkologi og selvfortællinger samt kontrol-interviews, der validerer de identificerede dimensioner og mønstre. Bülow fremanalyserer 6 nye læringsstrategiske dimensioner og identificerer 5 læringsstrategiske mønstre, hvoraf 2 er pragmatiske, Surfer- og Kollaboratør-strategierne, 2 er idealistiske, nemlig Traditionalistog Forsker-strategierne, mens den femte er kreativ og legende, Kunstner-strategien. Konklusionen er, at eleverne har en mangfoldighed af tilgange til det at lære samt arbejder hen mod forskellige mål, hvilket kommer til udtryk i de forskellige læringsstrategiske mønstre.

I bidraget "Digitaliserede læringsfællesskaber - netstuderende og deres studiestrategier" undersøger Lyngsø og Borgnakke sygeplejestuderendes læreprocesser og studiestrategier på en netbaseret uddannelse. De to forskere har, som en del af Projekt Netbaseret sygeplejeruddannelse på VIA University College (2014-2019) fulgt 9 studerende på VIA University College gennem 2 år. Inspireret af Salmons e-pædagogiske design og Wengers definition af praksisfælleskaber er det bærende didaktiske element undervisernes planlægning og guidning gennem uddannelsen. Forfatterne diskuterer betydningen af digitale læringsforløb for studerendes læringsudbytte i henholdsvis højt og lavt præsterende studiegrupper. Det e-pædagogiske design sikrer imidlertid ikke i sig selv den studiemæssige succes. De digitaliserede læringsfællesskaber er afhængige af studerendes selvforvaltning af teknologibrugen, og at de formår at komme de faglige udfordringer i møde i online læringskontekst i eget hjem. Konklusionen er, at succesen bliver sikret gennem de studerendes selvforvaltende udvikling af studiegrupperne til digitaliserede læringsfællesskaber. 
Artiklen "Det digitale instinkt - Gymnasieelevers digitale praksis" beskæftiger sig med gymnasieelevers forståelser og erfaringer med digitale teknologier i deres skolearbejde med det formål at nuancere diskussionen om digitale kompetencer fra et elevperspektiv. Boie, Dalsgaard og Caviglia undersøger således hvordan elever "handler, søger, producerer og deltager [...] med digitale teknologier" og de går praksisfænomenologisk til værks med et omfattende empirisk materiale bestående af observationer og elevinterviews. Gennem analysen udfoldes hvorledes elever både betragter digitale teknologier i en målmiddel optik men også gennemgående som en oplevet instinktiv handlen, der er kendetegnet ved at gøre eleverne handlingsduelige. Oplevelsen af at være kompetent kultiveres gennem erfaring og rutiner med teknologien som læringspartner og eleverne kan forstås som long-term-practitioners. Elever er derfor hverken ukritiske mediebrugere eller digitalt indfødte men tilegner sig derimod digitale informations-, produktions- og deltagelseskompetencer gennem intuitionsbaserede læringsstrategier. Det konkluderes at netop fordi elevers digitale instinkt ikke altid er hverken bevidstgjort eller artikuleret er det vigtigt at arbejde med at styrke elevernes bevidsthed om begreber, processer og arbejdsmetoder ved at synliggøre digital teknologi som kognitiv handlingspartner.

Peer-feedback mellem studerende via screencast er omdrejningspunktet i artiklen "Vi ved godt, at det bare er på 'note-plan' - Studerendes digitale læringsstrategier i peer feedback via screencast". Nordentoft og Møller undersøger, hvilke læringsstrategier studerende tager i brug til at give feedback på hinandens skriftlige produktioner. Artiklen anskuer de studerendes strategiske gøren ud fra et kombineret symbolsk interaktionistisk og dialogisk teoretisk perspektiv, konkretiseret ved inddragelse af henholdvis Goffmann og Bakhtin. Gennem en minutiøs analyse af studerendes videofeedback, der både indbefatter det talte og det kropslige, konkluderes det, at de studerende særligt benytter sig af tre distinkte feedbackstrategier. De giver hinanden meget tekstnær feedback, de metakommunikerer om den feedback de giver, og de tager forbehold for kritikken, de selv giver. Efter at have udfoldet disse tre feedbackstrategier i dybden, diskuterer forfatterne, hvorledes kritik og anerkendelse går hånd i hånd hvis asyknron videofeedback skal være fremmende for læringsudbyttet. Det handler især om at etablere et respektfuldt og forventningsafstemt rum hvor jagten på "rigtige" og entydige svar træder i baggrunden og hvor åbenhed over for forskellige subjektive stemmer gøres til en akademisk dyd i sig selv.

\section{Referencer}

Caviglia, F., Dalsgaard, C., O'Donovan, M. \& Andersen, M. (2019). STAK - Introduktion til akademiske digitale kompetencer: Center for Undervisningsudvikling og Digitale Medier, Aarhus Universitet.

Christensen, I.-M. F. (2017). Nye rammer for læring - padlets og no devices - et projekt om underviser-og undervisningsudvikling Gymnasiepædagogik 107. "De muligheder vi har..."-i forhold til frafald og kvalitet (s. 51-98): Institut for Kulturvidenskaber Syddansk Universitet.

Christensen, P. H. (2018). Kig op! Undervisning uden et blåt skær: Samfundslitteratur.

Henderson, M., Selwyn, N., Finger, G. \& Aston, R. (2015). Students' everyday engagement with digital technology in university: exploring patterns of use and 'usefulness'. Journal of Higher Education Policy and Management, 37(3), 308-319. doi:10.1080/1360080x.2015.1034424

Johnson, L., Adams Becker, S., Cummins, M., Estrada, V., Freeman, A. \& Hall, C. (2016). Horizon report. 2016 Higher Education Edition. Austin, Texas: The New Media Consortium.

McCombs, B. L. (2017, April). Historical review of learning strategies research: strategies for the whole learner-A tribute to Claire Ellen Weinstein and early researchers of this topic. In Frontiers in Education (Vol. 2, p. 6). Frontiers

Ryberg, T., Bertel, L. B., Sørensen, M. T., Davidsen, J. G. \& Konnerup, U. (2020). Hybridity, Transparency, Structured Freedom and Flipped Engagement-an Example of Networked Learning Pedagogy. Paper præsenteret på Proceedings of the twelth international conference on networked learning. 


\section{Redaktører}

\section{Mikkel Hvidtfeldt Andersen}

Specialkonsulent

IT-Universitetet

\section{Inger-Marie F. Christensen}

Ph.d.-studerende

Syddansk Universitet

\section{Ulla Konnerup}

Lektor, Ph.d.

Aalborg Universitet
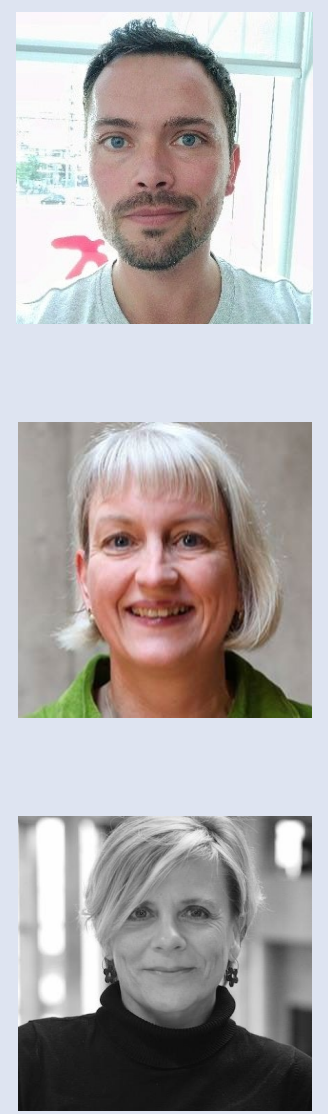